\title{
Chapter 27 \\ Adaptation to Climate Change \\ by Vegetable Farmers in Sri Lanka
}

\author{
R. P. Dayani Gunathilaka and P. S. M. Kalani J. Samarakoon
}

\section{Key Messages}

- Farmer characteristics such as gender, education level, and willingness to take credit influence resilience to climate change.

- Availability of updated climate information and improved extension services are instrumental in effective adaptation.

- Networking of farmers for initiating an information portal will nurture successful resilience.

\subsection{Introduction}

A substantial volume of economic and scientific studies have focused on the impact of climate change on agriculture. The agricultural sector's inherent vulnerability to weather and its significant role in developing countries are reasons for this growing concern (Blanc \& Reilly, 2017; Chalise et al., 2017; Huong et al., 2019). South Asia is one of the regions most affected by climate change (Cai et al., 2016; Aryal et al.,

\footnotetext{
Disclaimer: The presentation of material and details in maps used in this book does not imply the expression of any opinion whatsoever on the part of the Publisher or Author concerning the legal status of any country, area or territory or of its authorities, or concerning the delimitation of its borders. The depiction and use of boundaries, geographic names and related data shown on maps and included in lists, tables, documents, and databases in this book are not warranted to be error free nor do they necessarily imply official endorsement or acceptance by the Publisher, Editor(s) or Author(s).
}

R. P. D. Gunathilaka (凶) · P. S. M. K. J. Samarakoon

Department of Export Agriculture, Uva Wellassa University, Badulla, Sri Lanka

e-mail: dayani@uwu.ac.lk

P. S. M. K. J. Samarakoon

e-mail: kalanijaya25@gmail.com 
2019). According to the fifth assessment report of the Intergovernmental Panel on Climate Change (IPCC), it is predicted that the temperature will rise by $2{ }^{\circ} \mathrm{C}$ on average, hot days will increase in frequency, and unpredictable rainfall patterns will become more frequent and severe with shorter rainfall periods in South Asia by the mid-twenty-first century (Hijioka et al., 2014). In light of the fact that three-fifths of the cropping area of the region is rain-fed, extreme weather events such as floods and droughts will have severe impact on the rural poor and on agriculture (Jat et al., 2016; Esham et al., 2018; Aryal et al., 2019; Ahmed, 2022, Chap. 7 of this volume; Kattel \& Nepal, 2021, Chap. 11 of this volume).

Consistent with the projections for South Asia, Sri Lanka is already experiencing climate change and the consequent, erratic rainfall and extreme swings between droughts and intense rainfall (Chithranayana \& Punyawardena, 2014; Esham et al., 2018). For example, the island has been exposed to 30 large-scale flooding events between 2000 and 2018 and in 2016-2017 the country experienced a drought which was considered to be the worst such event in the past 40 years, affecting 20 districts and approximately 1.8 million people (Esham et al., 2018; United Nations Office for Disaster Risk Reduction, 2019). Data from the Food and Agriculture Organization (FAO) indicates that severe droughts followed by heavy rainfall have affected cropping areas in Sri Lanka, threatening the food security of some 900,000 people (FAO, 2017). Given that only $34 \%$ of the cultivated area in Sri Lanka is irrigated, the consequences of climate extremes have become critical causing serious implications for food production and rural livelihoods. Therefore, comprehensive understanding of the impacts on different food systems and adaptation measures is necessary to minimize the negative impacts and ensure local food security.

There is an expanding body of research to assess and quantify the impact of climate change on the Sri Lankan agriculture sector in general and principal crops such as tea, rubber, coconut, and paddy, in particular (Seo et al., 2005; De Silva et al., 2007; De Costa, 2010; Chithranayana \& Punyawardena, 2014; Gunathilaka et al., 2017; Chandrasiri et al., 2020). However, only a few studies have been focused on investigating farmers' adaptation to climate change. For example, Gunathilaka et al. (2018) analyze Sri Lankan tea estate managers' perceptions of climate change impacts, factors which affect their choice of current and potential future adaptation options, and barriers to the adoption of these options. Studies by Menike and Arachchi (2016) and Esham and Garforth (2013) analyze farmers' perception and observations on climate change, actual adaptation at farm level, and factors affecting mainly paddy and vegetable mix farming communities in Sri Lanka. Neither these studies nor other studies examine farmers' responses to minimize the negative impacts of climate change on up-country vegetable farming which provides promising opportunities for employment and an essential source of food and nutrition security in Sri Lanka. Therefore, in this chapter, we investigate farmers' ongoing adaptation to climate change, what factors drive farmers' decision to adapt and barriers to adaptation, based on the case of up-country vegetable farmers in Sri Lanka.

Employing data collected through face-to-face interviews with $150 \mathrm{Up}$-country vegetable farmers, this study focuses on the following research questions: (i) what are farmers' perceptions of climate change? (ii) which adaptation options are farmers 
currently adopting? (iii) which factors influence the commonly used adaptation options? (iv) what are the policy implications of commonly used adaptation options for long-term sustainability? The paper is structured as follows: Sect. 27.2 describes the context and climate-related impacts on vegetable farming. Section 27.3 provides the study area and sample characteristics. Section 27.4 presents the methodology. Section 27.5 describes results and discussion along with farmers' observations of the impacts of climate change on vegetable farming. Section 27.6 concludes with policy implications.

\subsection{Vegetable Farming: Context and Climate-Related Impacts}

Sri Lanka has a tropical climate and virtually no distinct seasons as the temperatures vary, on average between 27 and $30{ }^{\circ} \mathrm{C}$ in most regions of the island. The up-country ${ }^{1}$ area is at an altitude of about $1000 \mathrm{~m}$ above mean sea level where Nuwara Eliya has the coolest and mildest climate with mean temperature of $16^{\circ} \mathrm{C}$. Other upland areas (i.e., Badulla, Bandarawela, and Welimada) also experience a temperate climate that can span between 16 and $20^{\circ} \mathrm{C}$.

Sri Lankan agriculture is divided into two groups namely the plantation and nonplantation sector. Tea, rubber, and coconut together make the plantation crop sector. Non-plantation sector comprises of mainly paddy, vegetables, fruits, and field crops. After paddy, the vegetable subsector is the most prominent and consists of two categories namely low-country and up-country vegetables. Up-country vegetables are cultivated primarily in Nuwara Eliya and Badulla districts of the central highlands of Sri Lanka. Potato, leeks, carrot, beetroot, beans and cabbages are the main vegetables and contribute to Sri Lankan nutritional requirements as a source of vitamins, minerals, and fiber (Perera \& Madhujith, 2012; Padmajani et al., 2014).

\subsection{Study Area and Sampling}

We selected Nuwara Eliya, Welimada, Badulla, and Bandarawela divisional secretariats as the study area (Fig. 27.1). These four areas represent three different agro-ecological regions (AERs) ${ }^{2}$ namely up-country wet zone 3 (Nuwara Eliya), up-country intermediate zone 2 (Badulla), and up-country intermediate zone 3 (Bandarawela and Welimada). According to the Department of Census and Statistics as of 2018, 48,960 farmers were involved in vegetable farming in the study area.

\footnotetext{
${ }^{1}$ Similarly it is called hill country encompassing districts of Nuwara Eliya and Badulla.

${ }^{2}$ Agro-ecological regions (AER) are categorized based on rainfall, elevation, and soil type. Sri Lanka comprises 46 AERs.
} 


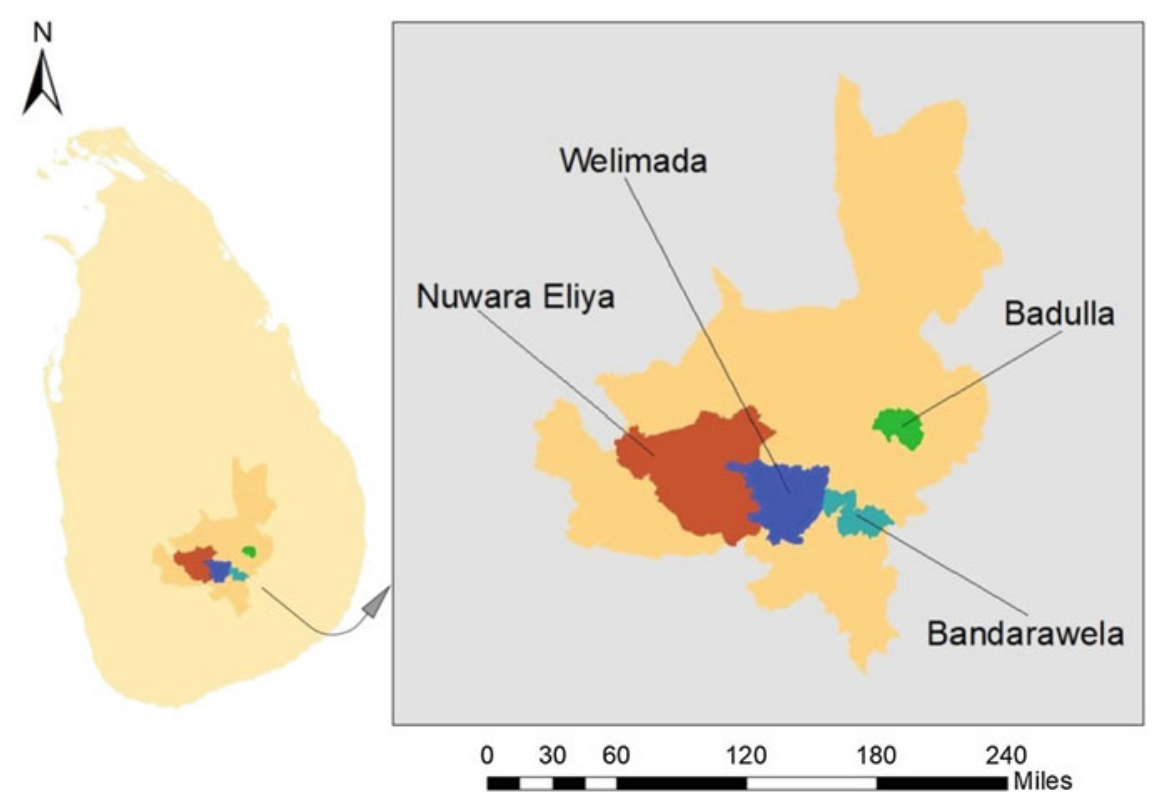

Fig. 27.1 Study area showing the selected divisional secretariats. Source Generated by Authors

Using a simple random sampling technique, 150 up-country vegetable farmers were selected for the study. The sampling fraction of farmers from each area was determined on the basis of the farmer population in the respective area. Accordingly, 44\% from Nuwara Eliya, 34\% from Welimada, 14\% from Bandarawela, and 8\% from Badulla were included in the sample.

\subsection{Methods and Variables}

We surveyed the farmers using an in-depth semi-structured interviewing method. The semi-structured questionnaire comprised of both open-ended and close-ended questions and was tested prior to the actual interview to determine validity and appropriateness of the climate change options and driving variables employed in the climate adaptation model here. Table 27.1 shows the variables and types of data collected. The interviews took place between September and November 2019 and obtained data detailing the farmers' age and experience, observations on changes in weather and climate (i.e., temperature, rainfall, drought, wind, and frost patterns) over the course of farming, perceptions of climate change and climate-related risks to their businesses, and responses to climate change and barriers to adaptation. The interviews averaged about $30 \mathrm{~min}$ each (Fig. 27.2). All interviews were recorded and then transcribed for subsequent analysis. 
Table 27.1 Data types

\begin{tabular}{|c|c|c|}
\hline Variable & Data & Data source \\
\hline \multirow[t]{4}{*}{ Dependent } & No adaptation & \multirow{4}{*}{$\begin{array}{l}\text { The literature and } \\
\text { survey }\end{array}$} \\
\hline & Early or late planting & \\
\hline & Switching variety or crop & \\
\hline & Intensive use of inputs & \\
\hline \multirow[t]{10}{*}{ Independent } & Gender of the farmer & \multirow[t]{8}{*}{ Survey } \\
\hline & Education level & \\
\hline & Farming experience & \\
\hline & Income of the farmer & \\
\hline & Willingness to take credit & \\
\hline & Extension on crop & \\
\hline & $\begin{array}{l}\text { Information on climate } \\
\text { change }\end{array}$ & \\
\hline & $\begin{array}{l}\text { Farmer-to-farmer } \\
\text { extension }\end{array}$ & \\
\hline & Total annual rainfall & \multirow[t]{2}{*}{ NRMC } \\
\hline & $\begin{array}{l}\text { Average annual } \\
\text { temperature }\end{array}$ & \\
\hline
\end{tabular}

Source Generated by Authors

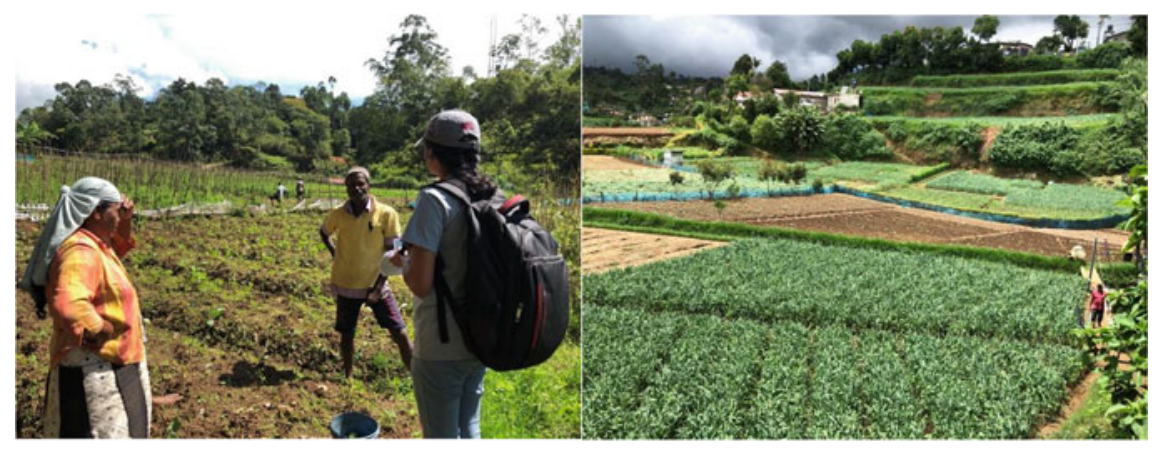

(a)

(b)

Fig. 27.2 a Interviewing a farmer in Welimada area. b Vegetable farm in Nuwara Eliya area. Photo courtesy Kalani Samarakoon

Temperature and rainfall data from 2001 to 2018 was obtained from the Natural Resource Management Centre (NRMC) of Sri Lanka. Proxy variable for climate change was constructed taking the percentage change of long-term mean of annual temperature and annual total rainfall. We consider the deviation of long-term mean of the period 2001 to 2009 from that of the period 2010 to 2018. 
The study analyzes factors affecting climate change by using a multinomial logit (MNL) model. In this study, MNL model was used based on the previous literature (Belay et al., 2017; Gunathilaka et al., 2018). This model is effective when analyzing decisions across more than two categories (Deressa et al., 2009). Thus, through MNL analysis, this study finds factors influencing the choice of farmers' commonly used adaptation options.

\subsection{Results and Discussion}

\subsubsection{Characteristics of the Sample}

The majority of respondents $(85 \%)$ were male farmers. As the agriculture sector consists of $33.5 \%$ female and $65.3 \%$ male farmers, this result is as expected. Mean farmland size was 253.02 perches ( 0.639 ha), and mean household size was four. Among respondents, about 3\% had 1-5 years of farming experience while around $20 \%$ each had 16-20 years and above 31 years of experience. Nearly four-fifth of the farmers (79\%) were over 39 years of age and $92 \%$ of farmers had at least senior secondary education. ${ }^{3}$

\subsubsection{Farmers' Perceptions on Climate Change}

Respondents were from three different agro-ecological regions and they had observed changes in the rainfall pattern, temperature, drought occurrence, and frost conditions. Almost all the farmers (98\%) have heard the term "climate change" and $97 \%$ of respondents believed climate change is ongoing. In addition, more than $85 \%$ of respondents believed that human activities are substantially contributing to climate change and $11 \%$ of respondents believed climate change is a natural thing.

Nearly all respondents $(99.33 \%)$ said that they were experiencing changes in climate.

In the past, rainy season in Nuwara Eliya was from April to December and the dry period was January to April. Farmers planned their work according to this rainfall pattern. But now this pattern has changed. (Farmer \#39, Nuwara Eliya)

Furthermore, in responding to the changes in rainfall pattern, farmers said they alter planting time for different crop types and varieties.

In the past we did not commence planting potato in June and July. But now, we can plant potato even in June and July. Still we cannot clearly understand this change in the climate.

\footnotetext{
${ }^{3}$ Those who passed grade 10-11 are categorized under the senior secondary level of education in Sri Lanka.
} 
Farmers' observed changes in climate

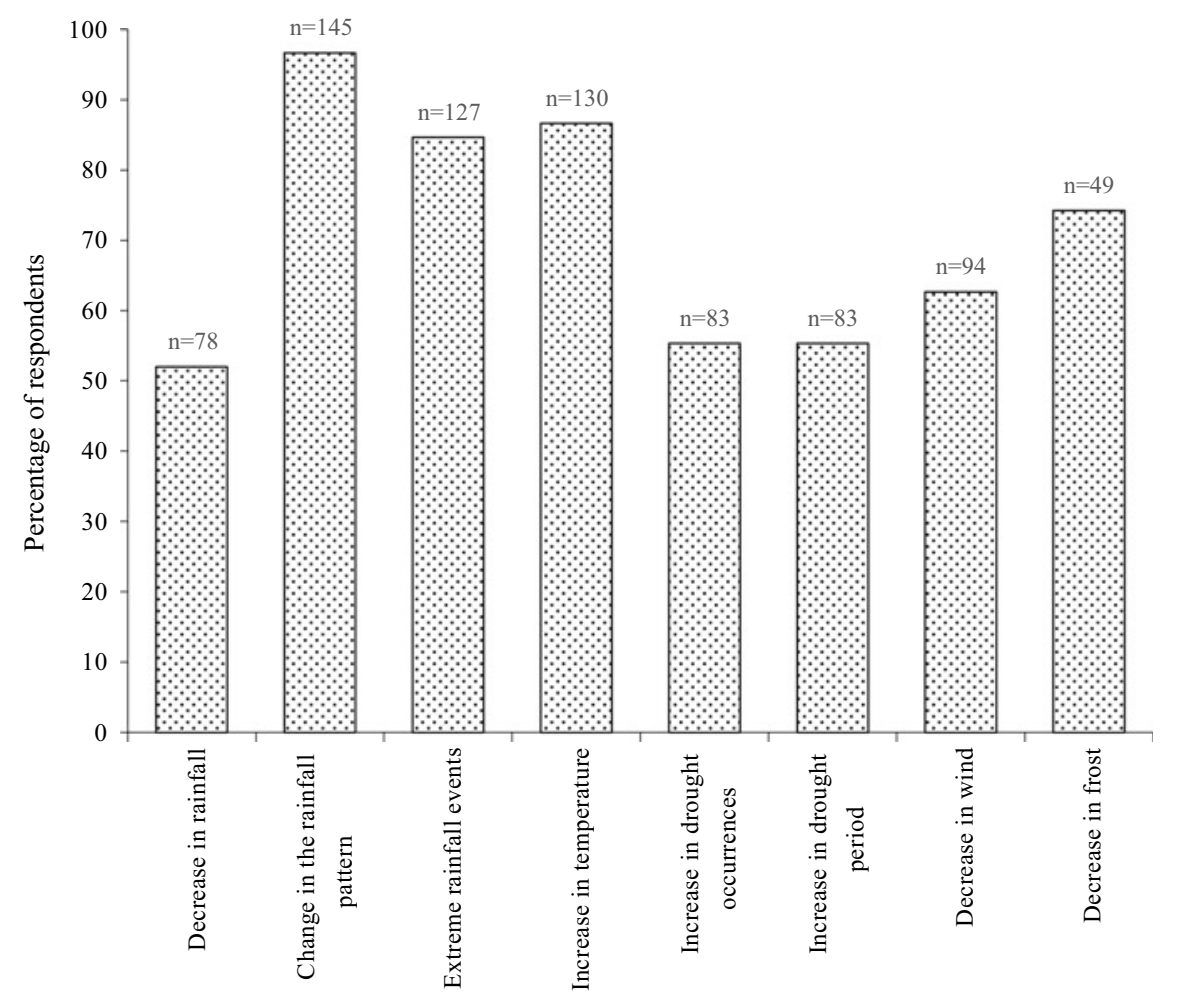

Observed changes in climate

Fig. 27.3 Farmers' observed changes in climate. Source Generated by Authors

If we observe a similar climate pattern for three or four consecutive years, we will be able to predict what will happen in next year. (Farmer \#41, Nuwara Eliya)

Survey results revealed that farmers have observed numerous changes in climate over the years. Figure 27.3 depicts farmers' observed changes about climate.

\subsubsection{Farmers' Observations on Climate Change Impacts}

More than $82 \%$ of farmers said they were experiencing negative impacts of climate change on their farming while the rest said it had both negative and positive effects. Nearly $75 \%$ of the responders said they were trying to minimize impacts of climate change through adaptation methods. 
Results revealed that farmers face difficulty in controlling pest attacks and diseases. Consequently, they have had to alter cropping plans and bear yield and income losses.

Not like in the past, most of times we receive extreme rainfalls and that damages our crops. Also there are lots of pest outbreaks that happen during the extreme rainfall periods. In this area, we can harvest an average of about $20 \mathrm{~kg}$ of beans, but today I plucked only $5 \mathrm{~kg}$. I had to throw about $10 \mathrm{~kg}$ of beans because of brown spot disease. Heavy rainfall worsens the spread and severity of this disease. I can earn around one and a half million rupees ${ }^{4}$ as income if we can sell it for a good market price, but I received only three to four hundred thousand for the last three years as a result of these negative impacts. I lost eight hundred thousand rupees in this season. (Farmer \#56, Nuwara Eliya)

Long-lasting fungal diseases, vegetable rotting, and increased cost of production are some of the negative impacts stated by the respondents.

Rainfall lasting for long period increases the spreading of black rot of cabbage. It is difficult to control potato blight during the period of heavy rains. Weather is unpredictable and it is difficult to plan pest and disease control practices. (Farmer \#40, Nuwara Eliya)

According to the farmers, planting of tuber crops should be done avoiding rainy season. However, farmers now face challenges in finding a suitable time for planting since the rainy season is unpredictable. Consequently, they experience huge crop losses.

Last year my harvest was exactly 50 sacks of carrot by just sowing two tins of seeds. But this year, I received only four sacks. My crop rotted because of rainfall lasted for long period. (Farmer \#65, Nuwara Eliya)

Seventy-two percent of farmers consider weather and weather-related information while taking decisions on cultivation and farm management practices. Most of the farmers believe their yield and revenue vary over the years due to climate change.

I have been cultivating 10 acres of vegetables and sometimes I could earn two million rupees from that cultivation. On the other hand, sometimes I lose one to one and half million rupees. I believe these losses are due to the climate change. (Farmer \#39, Nuwara Eliya)

\subsubsection{Farmers' Adaptation Options}

The results revealed that vegetable farmers have been practicing different adaptation options to minimize climate change impacts. These adaptation options include, early or late planting, switching variety or crop and intensive use of inputs. In this study "no adaptation" was selected as the base category to express relative probabilities in the climate adaptation model.

Climate during the past twenty years has changed dramatically and forced us to switch the variety or the crop and change the planting time. Some farmers are unable to adopt any adaptation measure mainly because of their financial constraints. (Farmer \#39, Nuwara Eliya)

\footnotetext{
${ }^{4}$ LKR $189.84=$ USD 1 in December 2020.
} 
Switching variety or crop was adopted by more than $42 \%$ farmers as the most common response for adaptation.

We change the type of crop cultivating and select the crops according to the weather pattern. Cabbage is good for this time since we have adequate rainfall. But it is difficult to protect potato and carrot farms since it is heavy rains. (Farmer \#47, Nuwara Eliya)

Early or late planting was adopted by $23 \%$ of respondents. Moreover, most of the farmers stated that rainfall seasons ${ }^{5}$ have now changed and they are unable to make cropping calendars according to well-known monsoon patterns as they did earlier. As a result, they have to make sudden decisions for their farming and find it hard to plan any farming operations beforehand.

Earlier we used to start cultivation in October, but now since rain starts earlier, we are planting before October. (Farmer\#16, Nuwara Eliya)

Referring to another farmer,

For blight, in the past we used fungicides at five days interval but now we spray it in three days interval. When rain is heavy, there are times that we use fungicides every other day. (Farmer \#24, Bandarawela)

Intensive use of inputs was adopted by $34 \%$ of farmers as a commonly used adaptation. Nearly all respondents who have adopted this method revealed that they do not increase the amount of fertilizer. However, they use pesticides, fungicides, and weedicides intensively.

In summary, most of the farmers have started to respond to the impacts of climate change mainly through early or late planting, switching variety or crop and intensive use of inputs.

\subsubsection{Drivers of Farmers' Choice of Adaptation}

Prospective-independent variables were determined with regard to the literature, availability of data, and pretest. These can be broadly categorized as demographic, socioeconomic, and climate change-related factors. Table 27.2 describes the explanatory variables used in the model.

Different combinations of independent variables were tested out of 14 variables which were collected from semi-structured in-depth interviews. In the preliminary stage, household size and farmland size variables were dropped, as those variables were not significant. Furthermore, independent variables, namely farm income, total income of the farmer, farmer-to-farmer extension, and age of the farmer were tested (model was run with and without those variables) with MNL model. Results indicated that inclusion of farm income and age of the farmer does not make parameter

\footnotetext{
${ }^{5}$ Southwest monsoon season is from May to September and northeast monsoon season prevails from December to February (Department of Meteorology, Sri Lanka).
} 
Table 27.2 Description of explanatory variables used in MNL model

\begin{tabular}{l|l|l|l}
\hline Explanatory variable & Mean & SD & Description \\
\hline Gender of the farmer & 0.85 & 0.36 & Dummy, $1=$ male, $0=$ otherwise \\
\hline Education level & 2.41 & 0.79 & Categorical (level of education) \\
\hline Farming experience & 4.67 & 1.71 & Categorical (year categories) \\
\hline Income of the farmer & 3.44 & 1.38 & Categorical (income categories) \\
\hline Willingness to take credit & 0.43 & 0.50 & Dummy, 1 = willing, 0 = otherwise \\
\hline Extension on crop & 0.49 & 0.50 & Dummy, 1 = adequate, 0 = otherwise \\
\hline Information on climate change & 0.22 & 0.42 & Dummy, 1 = sufficient, 0 = otherwise \\
\hline Farmer-to-farmer extension & 0.80 & 0.40 & Dummy, 1 = helpful, 0 = otherwise \\
\hline Total annual rainfall & 7.28 & 3.96 & $\begin{array}{l}\text { Continuous (percentage change in average } \\
\text { annual rainfall between the years } \\
\text { 2001-2009 and 2010-2018) }\end{array}$ \\
\hline Average annual temperature & 0.05 & 1.09 & $\begin{array}{l}\text { Continuous (percentage change in average } \\
\text { annual temperature between the year } \\
\text { 2001-2009 and 2010-2018) }\end{array}$ \\
\hline
\end{tabular}

Source Generated by Authors

estimates and marginal effects significant, although total income of the farmer and farmer-to-farmer extension made results significant.

Final combination of explanatory variables was selected based on model fit and statistical significances of marginal effects, as it is the most important result outcome in MNL model.

Model was tested for independence of irrelevant alternatives (IIA) by using seemingly unrelated post-estimation procedure (SUEST) (Deressa et al., 2009; Gunathilaka et al., 2018). SUEST test failed to reject null hypothesis in independence of irrelevant alternatives indicating MNL is appropriate to use for the sample.

\subsubsection{Explanation of Variables}

The effects of each significant variable on probability of different adaptation options adopted by farmers are explained below.

i. Gender: Being a male farmer increases the probability of adopting early or late planting by $14.8 \%$.

ii. Education level: Education of the farmer has a positive effect on switching variety or crop. Well-educated farmers are $11.7 \%$ more likely to switch variety or crop as an adaptation to climate change. Education level relates negatively to intensive use of inputs. One unit increase in the level of education would result in $11.8 \%$ decrease in the intensive use of inputs. This result is intuitive given farmers with broad knowledge about suitable crops and varieties tend 
to explore the associated adaptation methods. Similarly, educated farmers recognize harmful effects of intensive input use and reduce usage.

iii. Farming experience: Farming experience has a positive and significant impact on early or late planting. Experienced farmers are $4.5 \%$ more likely to practice early or late planting. With experience farmers identify climate change trends and they adjust their cropping calendars according to the changes.

iv. Income: As expected, income has a positive influence on adaptation. Thus, farmers with high-income levels prefer more adaptation. Increase in farmers' income increases the probability of switching variety or crop by $6.8 \%$. The results further emphasize that farmers with higher-income levels can afford adaptation and switching costs.

v. Willingness to use credit: Willingness to use credit has a significant positive effect on adaptation. Farmers with financial problems are willing to use credit as they want capital to minimize the impact of climate through adaptation.

vi. Extension services on crop: As expected, the access to crop extension has a positive and significant effect on adaptation. Precisely, the extension on crop increases the likelihood of early or late planting by $12.3 \%$. Results emphasize the crucial role of disseminating information about climate change and crops. Moreover, farmers receive better knowledge about climate change through extension and are confident to alter planting time.

vii. Information on climate change: Access to climate change information has a significant positive effect on adaptation. Moreover, farmers who receive information on climate change are $19.3 \%$ more likely to select switching variety or crop as their commonly used adaptation option.

viii. Farmer-to-farmer extension: Having access to farmer-to-farmer extension has a positive and significant effect on adaptation. The results imply that the adaptation is encouraged by their social network.

ix. Percentage change in average annual rainfall: Farmers who have experienced an increasing percentage of average annual rainfall are more likely to adopt switching variety or crop by $3.9 \%$. This result indicates that farmers switch variety or crop with rainfall changes but do not change the time of planting. As farmers cannot wait until rainfall decreases, they select vigorous crops or varieties to cultivate.

x. Average annual temperature: Unlike increasing percentage of average annual rainfall, higher level of average annual temperature appears to work opposite in terms of adaptation. This may be probably because increasing percentage of average annual rainfall relaxes the implications caused by increasing percentage of average annual temperature on crops and vegetable farming is more sensitive to rainfall and availability of water rather than temperature. 


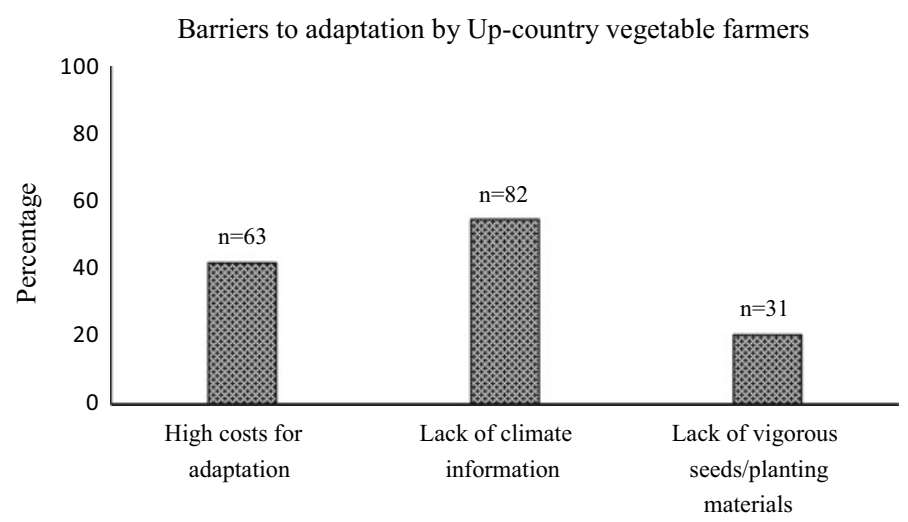

Barriers to adaptation

Fig. 27.4 Barriers to adaptation by up-country vegetable farmers. Source Generated by Authors

\subsubsection{Barriers to Adaptation}

We employed a descriptive analysis for the qualitative data gathered on barriers to adopt. Lack of climate information, high costs for adaptation and lack of vigorous seed and other planting materials were the three most common barriers stated by the respondents (Fig. 27.4). All non-adapters ${ }^{6}$ mentioned insufficient climate change information as a major barrier for adaptation. A disappointing point to note is more than $70 \%$ of adopters did not have access to sufficient climate change information. Thus, lack of information was the most cited constraint faced by the farmers $(82 \%)$.

Some farmers mentioned that though they attempt to identify climate patterns, they could not figure these out as they are not capable of analyzing the data.

We do not receive near-accurate weather forecasts. Therefore, we have no trust on weather forecasts. If farmers can reach accurate weather information beforehand, it will be a great help for us to plan our cropping practices. (Farmer \#72, Welimada)

When we plan cultivation according to the previous season's rainfall pattern, it will not be the same in the current year. We cannot figure out the pattern of climate change". (Farmer \#31, Welimada)

There appears to be no adequate source of information regarding weather patterns through any source of media (i.e., TV, radio, newspapers). Hence, farmers are unable to plan their operations and end up in unprofitable and unsustainable farming. This information barrier was followed by high costs of adaptation (42\%). Although farmers want to switch crop or variety, they find it challenging for adaptation since the switching cost is high. Some farmers mentioned that low-income farmers do not wait until suitable environmental conditions arise to commence cultivation and management practices.

\footnotetext{
${ }^{6}$ Non-adapters referred here are the respondent farmers who are not adapted to climate change.
} 
Financially stable farmers plant potatoes in February and harvest in June or July. They wait for harvesting to a better market price. But we cannot wait like them because of financial problems. We have families to feed. These days we are planting short term crops like, Chinese items (Lettuce, coriander) so we can earn some money in short run. (Farmer \#50, Nuwara Eliya)

Another major constraint stated by respondents is lack of availability of vigorous seed and other planting materials. Most of the responders have no reliance on new hybrid varieties. They feel hybrid varieties cannot withstand climate change:

There are new blight resistant potato varieties. Although they produce leaves nicely, tubes do not grow adequately. We face problems in selecting proper varieties. (Farmer \#55, Nuwara Eliya)

Lack of crop insurance policies also obstructs the farmers' adaptation to climate change. Thus, crop insurance programs should be customized according to the needs of vegetable farmers and in particular to the Up-country.

Crop insurance policies should be changed in a way that it will appropriate and benefit to the Up-country vegetable farmers. Current crop insurance procedure is made for the paddy farmers. It has three steps. Fund is released at the third step. But for potato, this procedure is not suitable because most expenses occur during the early stages of potato cultivation. Therefore, crop insurance should be given for the damages that are occurring in early stages (1st step). Often we receive insurance claim after about nine months of application, so it is too late. (Farmer \#40, Nuwara Eliya)

\subsection{Conclusions}

Farmer adaptation practices are influenced by many factors. Understanding these factors is important in developing effective and appropriate policies and programs related to climate change adaptation. This study investigates climate change adaptation and factors driving the adaptation of vegetable farmers in Sri Lanka. There are three commonly used adaptation options which are early or late planting, switching variety or crop and intensive use of inputs.

By assessing the drivers of adaptation by the farmers, we identify that several characteristics such as gender of the farmer, education level, farming experience, income of the farmer, and willingness to take credit are important when encouraging farmers toward adaptation. The drivers related to information availability for the farmers, e.g., extension on crop, information on climate change, farmer-to-farmer extension, and climate variables themselves are affecting adaptation. Among these factors, education level, willingness to take credit, extension on crops, and information on climate change are highly likely to influence farmers' adaptation through policy interventions.

Information constraints emerge as a major barrier followed by high costs for adaptation and lack of vigorous seeds and other planting materials. Creating welldefined crop extension service and initiating convenient access for reliable and updated climate information could leverage sustainable vegetable farming systems. 
Moreover, designing and implementation of a systematic credit system may further promote adaptation. Disseminating climate education through agricultural societies and extension services would require restructuring since farmers are in a dire need of information such as selection of suitable varieties and access to planting materials of these varieties. Educating the farming community, providing comprehensive climate information and improved crop extension service can be underlined as practices which need governmental support. Furthermore, regulating vegetable seed importation, implementing policies based on new research findings, and incentivizing studies on climate change is pivotal. Networking of farmers to initiate an information portal will nurture climate change adaptation among up-country vegetable farmers. All in all, the adaptation strategies incorporated with local knowledge and practices may feasibly result in effective and sustainable adaptation to climate change. This could enhance the up-country vegetable farming community's resilience for climate change consequences.

\section{References}

Ahmed, A. (2022). Autonomous adaptation to flooding by farmers in Pakistan. In A. K. E. Haque, P. Mukhopadhyay, M. Nepal \& M. R. Shammin (Eds.), Climate change and community resilience: Insights from South Asia (pp. 101-112). Springer Nature.

Aryal, J. P., Sapkota, T. B., Khurana, R., Khatri-Chhetri, A., \& Jat, M. (2019). Climate change and agriculture in South Asia: Adaptation options in smallholder production systems. Environment Development and Sustainability, 22(6), 5045-5075.

Belay, A., Recha, J. W., Woldeamanuel, T., \& Morton, J. (2017). Smallholder farmers' adaptation to climate change and determinants of their adaptation decisions in the Central Rift Valley of Ethiopia. Agriculture and Food Security, 6(1).

Blanc, E., \& Reilly, J. (2017). Approaches to assessing climate change impacts on agriculture: An overview of the debate. Review of Environmental Economics, 11(2), 247-257.

Cai, Y., Bandara, J. S., \& Newth, D. (2016). A framework for integrated assessment of food production economics in South Asia under climate change. Environmental Modelling and Software, 75, $459-497$.

Chalise, S., Naranpanawa, A., Bandara, J. S., \& Sarker, T. (2017). A general equilibrium assessment of climate change-induced loss of agricultural productivity in Nepal. Economic Modelling, 62, 43-50.

Chandrasiri, S., Galagedara, L., \& Mowjood, M. (2020). Impacts of rainfall variability on paddy production: A case from Bayawa minor irrigation tank in Sri Lanka. Paddy and Water Environment, 18, 443-454.

Chithranayana, R. D., \& Punyawardena, B. V. R. (2014). Adaptation to the vulnerability of paddy cultivation to climate change based on seasonal rainfall characteristics. Journal of the National Science Foundation of Sri Lanka, 42(2), 119-127.

De Costa, W. (2010). Adaptation of agricultural crop production to climate change: A policy framework for Sri Lanka. Journal of the National Science Foundation of Sri Lanka, 38(2), 79-89.

De Silva, C., Weatherhead, E., Knox, J. W., \& Rodriguez-Diaz, J. (2007). Predicting the impacts of climate change-A case study of paddy irrigation water requirements in Sri Lanka. Agricultural Water Management, 93(1-2), 19-29.

Deressa, T. T., Hassan, R. M., Ringler, C., Alemu, T., \& Yesuf, M. (2009). Determinants of farmers' choice of adaptation methods to climate change in the Nile Basin of Ethiopia. Global Environmental Change, 19(2), 248-255. 
Esham, M., \& Garforth, C. (2013). Agricultural adaptation to climate change: Insights from a farming community in Sri Lanka. Mitigation and Adaptation Strategies for Global Change, 18(5), 535-549.

Esham, M., Jacobs, B., Rosairo, H. S. R., \& Siddighi, B. B. (2018). Climate change and food security: A Sri Lankan perspective. Environment, Development and Sustainability, 20(3), 1017-1036.

Gunathilaka, R., Smart, J., \& Fleming, C. (2017). The impact of changing climate on perennial crops: The case of tea production in Sri Lanka. Climatic Change, 140(3-4), 577-592.

Gunathilaka, R. P. D., Smart, J. C. R., \& Fleming, C. M. (2018). Adaptation to climate change in perennial cropping systems: Options, barriers and policy implications. Environmental Science and Policy, 82, 108-116.

FAO (2017) Special report on FAO/WFP crop and food security assessment mission to Sri Lanka. Retrieved from http://www.fao.org/3/i7450e/i7450e.pdf

Hijioka, Y., Lin, E., Pereira, J. J., Corlett, R. T., Cui, X., Insarov, G. E., Lasco, R. D., Lindgren, E. \& Surjan, A.(2014). Asia. In Working group II contribution to the IPCC fifth assessment report climate change (pp. 1327-1370).

Huong, N. T. L., Bo, Y. S., \& Fahad, S. (2019). Economic impact of climate change on agriculture using Ricardian approach: A case of northwest Vietnam. Journal of the Saudi Society of Agricultural Sciences, 18(4), 449-457.

Jat, M. L., Dagar, J. C., Sapkota, T. B., Govaerts, B., Ridaura, S. L., Saharawat, Y. S., Sharma, R. K., Tetarwal, J. P., Jat, R. K., Hobbs, H., \& Stirling, C. (2016). Climate change and agriculture: Adaptation strategies and mitigation opportunities for food security in South Asia and Latin America. Advances in Agronomy, 137, 127-235.

Kattel, R. R., \& Nepal, M. (2021). Rainwater harvesting and rural livelihoods in Nepal. In A. K. E. Haque, P. Mukhopadhyay, M. Nepal, \& M. R. Shammin (Eds.), Climate change and community resilience: Insights from South Asia (pp. 159-173). Springer Nature.

Menike, L. M. C. S., \& Arachchi, K. A. G. P. K. (2016). Adaptation to climate change by smallholder farmers in rural communities: Evidence from Sri Lanka. Procedia Food Science, 6, 288-292.

Padmajani, M. T., Aheeyar, M. M. M., \& Bandara, M. A. C. S. (2014). Assessment of pesticide usage in Up-country vegetable farming in Sri Lanka. Hector Kobbekaduwa Agrarian Research and Training Institute.

Perera, T., \& Madhujith, T. (2012). The pattern of consumption of fruits and vegetables by undergraduate students: A case study. Tropical Agricultural Research, 23(3), 261-271.

Samarakoon, P. S. M. K. J., \& Gunathilaka, R. P. D. (2020). Adaptation to climate change by Up-country vegetable farmers. In Proceedings of the International Research Conference of Uva Wellassa University, July 29-30, 2020.

Seo, S. N. N., Mendelsohn, R., \& Munasinghe, M. (2005). Climate change and agriculture in Sri Lanka: A Ricardian valuation. Environment and Development Economics, 10(5), 581-596.

United Nations Office for Disaster Risk Reduction. (2019). Disaster risk reduction in Sri Lanka, Status Report for 2019. Retrieved from Bangkok, Thailand, United Nations Office for Disaster Risk Reduction (UNDRR), Regional Office for Asia and the Pacific. https://www.unisdr.org/files/ 68230_10srilankadrmstatusreport.pdf 
Open Access This chapter is licensed under the terms of the Creative Commons AttributionNonCommercial-NoDerivatives 4.0 International License (http://creativecommons.org/licenses/bync-nd/4.0/), which permits any noncommercial use, sharing, distribution and reproduction in any medium or format, as long as you give appropriate credit to the original author(s) and the source, provide a link to the Creative Commons licence and indicate if you modified the licensed material. You do not have permission under this licence to share adapted material derived from this chapter or parts of it.

The images or other third party material in this chapter are included in the chapter's Creative Commons licence, unless indicated otherwise in a credit line to the material. If material is not included in the chapter's Creative Commons licence and your intended use is not permitted by statutory regulation or exceeds the permitted use, you will need to obtain permission directly from the copyright holder.

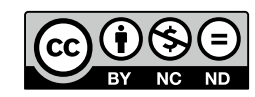

